\author{
Asian Journal of \\ Medical and Biological Research \\ ISSN 2411-4472 (Print) 2412-5571 (Online) \\ www.ebupress.com/journal/ajmbr
}

\title{
Article \\ Prevalence of canine parvo virus and canine influenza virus infection in dogs in Dhaka, Mymensingh, Feni and Chittagong districts of Bangladesh
}

\author{
Soumitra Sen ${ }^{1}$, Md. Siddiqur Rahman ${ }^{2}$, Minakshi Nag ${ }^{3}$, Mohummad Muklesur Rahman $^{4}$, Roma Rani Sarker ${ }^{2}$ \\ and S. M. Lutful Kabir ${ }^{*}$ \\ ${ }^{1}$ Department of Microbiology and Hygiene, Bangladesh Agricultural University, Mymensingh-2202, \\ Bangladesh \\ ${ }^{2}$ Department of Medicine, Bangladesh Agricultural University, Mymensingh-2202, Bangladesh \\ ${ }^{3}$ Department of Microbiology, Hajee Mohammad Danesh Science and Technology \\ University, Dinajpur-5200, Bangladesh \\ ${ }^{4}$ Veterinary Surgeon, District Veterinary Hospital, Gazipur, Bangladesh
}

${ }^{*}$ Corresponding author: Professor Dr. S. M. Lutful Kabir, Department of Microbiology and Hygiene, Faculty of Veterinary Science, Bangladesh Agricultural University, Mymensingh-2202, Bangladesh. Tel.: +88-09167401-6/Ext. 2394; Fax: +88-091-61510; E-mail: 1kabir79@gmail.com

Received: 10 March 2016/Accepted: 20 March 2016/Published: 31 March 2016

\begin{abstract}
Canine parvovirus (CPV) and canine influenza virus (CIV) are highly contagious virus infecting members of the canine family including dogs, coyotes, foxes and wolves. The research work was carried out to determine the prevalence of CPV and CIV in dogs (stray and pet dogs) in Dhaka, Mymensingh, Feni and Chittagong Districts by using Rapigen CPV and CIV Ag test kit. Fecal samples were collected from 50 dogs of different age and sex from different spots of Dhaka and Chittagong District. Nasal fluid samples were collected from 50 dogs of different age and sex from different spots. The samples were tested with Rapigen canine parvovirus Ag test kit and Rapigen canine influenza Ag test kit. Overall prevalence of CPV in pet dogs was $22 \%$ and in stray dogs was $30 \%$. The prevalence of canine parvovirus in relation to age was gradually decreasing with higher age group and the prevalence was $28 \%$ in 1-6 months age, $16.66 \%$ in $7-12$ months age group $11.11 \%$ o ver 18 months age group. The prevalence of canine parvovirus was significantly higher in male (24.13\%) than that in female (19.04\%). All samples showed negative test result for canine influenza virus. Prevalence of canine influenza virus infection were $00.00 \%$ in all age groups and sex. Overall prevalence of CIV in all pet and stray dogs were $00.00 \%$.
\end{abstract}

Keywords: FMD; Northern Plateau; seroprevalence; cattle; prevalence odd ratio

\section{Introduction}

Since the earlier days of history, dogs have been friends and servants of human. They have proved themselves to the faithful companions, staunch in adversity and capable of great endurance. Dog Squad is being employed in security assistance duties in various national, international and public events. Dog team of this unit is employed everyday as a mandatory part of security duties for VVIP/VIP's like Honorable President, Prime Minister Office. National Parliament announced various venues of National and international programmers and any other important place which needs special security attention. Canine parvovirus (CPV) suddenly emerged in the mid1970s and during 1978; it was recognized as the cause of a new disease in dogs throughout the world (Parrish, 1990). The original virus strain was called CPV type 2, but between 1979 and 1982 it was replaced by a new antigenic type called CPV type 2a (Parrish, 1988). Around 1984 another CPV strain called CPV type 2b emerged and by 1988 it was the predominant type. CPV is closely related to feline panleukopenia virus (FPV) and to the other autonomous parvoviruses that infect carnivores (Reed et al., 1988; Truyen et al., 1995). CPV and FPV differ in their antigenic and hemagglutination properties (Chang et al., 1992, Llamas-Saiz et al., 1996) 
as well as in their host range (Parrish, 1990; Steinel et al., 2001). The Canine Influenza Virus subtype H3N8 was first identified in January, 2004 during an outbreak of respiratory infection amongst Florida racing greyhounds. This virus is Influenza A virus and is closely related to the equine influenza virus. In fact, canine influenza is now considered to have originated when the equine influenza virus "jumped" species during the 1990's. In mammals, influenza viruses are usually transmitted in aerosols created by coughing and sneezing, and by contact with nasal discharges, either directly or on fomites. Close contact and closed environments favor transmission. The most well characterized subtype in the United States, H3N8, can cause two clinical syndromes. Majority of dogs develop in the milder syndrome, involving a cough that persists for 10 to 21 days despite therapy with antibiotics and cough suppressants. This syndrome can also include purulent nasal discharge and a low-grade fever. The more severe disease involves pneumonia, including a high fever $\left(104^{\circ}\right.$ to $106^{\circ} \mathrm{F}$ ) and increased respiratory rate and effort. Thoracic radiographs may show consolidation of lung lobes. Considering the above facts in the field of viral diseases diagnosis particularly for CPV and CIV in the street and pet dogs of Dhaka and Chittagong Division, present research work was undertaken to determine the prevalence and risk factor of canine parvovirus and canine Influenza virus (CIV) virus infection in stray and pet dogs of Dhaka, Myensingh, Feni and Chittagong districts. .

\section{Materials and Methods}

\subsection{Study area}

The sample collection of both Canine Parvovirus (CPV) and Canine Influenza Virus (CIV) was conducted at the S.A Quaderi Teaching Veterinary Hospital of Chittagong Veterinary and Animal Science University, Feni Girls Cadet College campus, Central Veterinary Hospital, Dhaka and Bangladesh Agricultural University (BAU) Campus during the period from January to June, 2014. The research work was conducted in the laboratory of the Department of Microbiology and Hygiene, Bangladesh Agricultural University, Mymensingh.

\subsection{Brief description of the experimental design}

A total of 50 rectal swab samples for CPV and nasal swab samples for CIV were collected randomly from stray and pet dogs. Rectal swab were collected before the dogs were euthanatized by the municipal authority and by taking permission of the owner. The stray dogs and the pet dogs studied were in different ages and mixed sexes and with no history of vaccination against canine parvovirus infection and canine influenza virus infection. The clinical signs specially the presence of diarrhea, coughing (10 - 21 days), purulent nasal discharge and other signs (if any) as well as age, sex were recorded carefully.

\subsection{Collection and processing of sample}

For all the assays, equal amount of fecal samples were collected from 50 dogs from different spot of Dhaka and Chittagong Division.

The majority of the rectal swab were collected from the age group of 1-6 months (25 out of 50), from 7-12 moths (12 dogs out of 50), from 13 to from over 18 months (13 dogs out of 50) and male (29 out of 50 dogs ), female dogs (21out of 50) and The majority of the nasal fluid swab were collected from the age group of 1-6 months (22 out of 50), from 7-12 moths (13 dogs out of 50), from 13-18 months (11 dogs out of 50), from over 18 months (4 dogs out of 50) and male (27 out of 50 dogs) female dogs (23 out of 50) with no previous treatment and vaccination record.

A total of $50 \mathrm{dogs}$ of different age, sex and location were evaluated and majority of fecal samples were collected from puppies under 6 months of age ( 25 out of 50), from stray dog (10 out of 50), from pet dog (40 out of 50) and a total of 50 dogs of different age, sex and location were evaluated and majority of the fecal samples were collected from puppies under 6 months of age ( 22 out of 50), from stray dog (10 out of 50), from pet dog (40 out of 50).

\subsection{Interpretation of the test of result for CPV and CIV}

Results of the test were interpreted within 10 minutes by visual observation of single band for negative control, double band (one control and other treatment) for positive test. A color band will appear in the left section of the result window to show that the test is working properly which is known as the control band (C). The right section of the result window indicates the test results. If another color band appears in the right section of the result window, this band is the test band $(\mathrm{T})$. The presence of only one band within the result window indicates a negative result. The presence of two color bands ( $\mathrm{T}$ and $\mathrm{C}$ ) within the result window, no matter which band appears first, indicates a positive result. If the purple color band is not visible within the result window after performing the test, the result is considered invalid. 


\section{Results}

The samples were tested with RapiGen canine parvovirus Ag kit test (CPV) and the test results have shown in Tables 1, 2, 3 and 4. In addition, the samples were tested with Rapigen canine influenza Ag kit test (CIV) and the test results have shown in Tables 5, 6 and 7. This study revealed that the overall prevalence of canine parvovirus and canine influenza virus in stray and pet dogs of Dhaka and Chittagong division as 11\% and $0 \%$. In which Dhaka Division as 25\% (7 out of 28 ) is CPV and $00.00 \%$ (0 out of 22) was CIV, In Chittagong Division as $18.18 \%$ (4 out of 22) was CPV and $00.00 \%$ (0 out of 22) was CIV . The Prevalence of canine parvovirus infection by RapiGEN canine parvovirus Ag kit test was 33.33\%(6 out of 18), 22.22\% ( 2 out of 9),14.28\% (1 out 7) and 25.00\% ( 1 out of 4) in dogs having diarrhea and of 1-6 months, 7-12 months, 1318 months and over 18 months age group and The Prevalence of canine influenza virus infection by Rapigen canine influenza virus Ag kit test was $00.00 \%$ (0 out of 22), 00.00\% ( 0 out of 13),00.00\% (0 out 11) and $00.00 \%$ ( 0 out of 4 ) in dogs having cough and of 1-6 months, 7-12 months, 13-18months and over 18 months age group. According to the sex the prevalence of CPV in Dhaka and Chittagong Division was $24.13 \%$ (7 out of 29) in male and $19.4 \%$ (4 out of 21) in female dogs, the prevalence of CPV in Dhaka and Chittagong Division was $00.00 \%$ ( 0 out of 27 ) in male and $00.00 \%$ (0 out of 23) in female dogs. Age wise the prevalence was relatively higher in 1-6 months (28.00\%) than that of 7-12 months age group (16.16\%) 13-18 months age group (11.11\%) and >18 months age group (25.00\%) for CPV and in 1-6 months (00.00\%), 7-12 months age group (00.00\%),13-18 months age group (00.00\%) and >18 months age group $(00.00 \%)$.

Table 1. Age related prevalence of Canine parvovirus.

\begin{tabular}{|c|c|c|c|c|c|c|}
\hline Age of the dog & $\begin{array}{l}\text { Number I of } \\
\text { Sample tested }\end{array}$ & $\begin{array}{l}\text { Number of } \\
\text { positive reactors }\end{array}$ & $\begin{array}{l}\text { Number of } \\
\text { negative reactors }\end{array}$ & $\begin{array}{l}\text { Percentage of } \\
\text { Positive } \\
\text { reactors }\end{array}$ & $\begin{array}{l}\text { Percentage } \\
\text { of negative } \\
\text { reactors }\end{array}$ & $\begin{array}{l}\text { Chi- } \\
\text { test }\end{array}$ \\
\hline $1-6$ months & 25 & 7 & 18 & $28.0 \%$ & $72.0 \%$ & 1.054 \\
\hline 7-12 months & 12 & 2 & 10 & $16.66 \%$ & $83.33 \%$ & \\
\hline $13-18<$ & 13 & 2 & 11 & $18.18 \%$ & $84.61 \%$ & \\
\hline
\end{tabular}

$\mathrm{P}$ value non-significant $(\mathrm{p}>0.05)$

Table 2. Prevalence of canine parvovirus according to age and presence and /or absence of diarrhea.

\begin{tabular}{lllllll}
\hline $\begin{array}{l}\text { Age of } \\
\text { Dog }\end{array}$ & $\begin{array}{l}\text { Presence } \\
\text { of } \\
\text { Diarrhea }\end{array}$ & $\begin{array}{l}\text { Number } \\
\text { of } \\
\text { Sample } \\
\text { tested }\end{array}$ & $\begin{array}{l}\text { Number } \\
\text { of } \\
\text { positive } \\
\text { reactors }\end{array}$ & $\begin{array}{l}\text { Total no. } \\
\text { of diarrheic } \\
\text { dogs }\end{array}$ & $\begin{array}{l}\text { Percentage } \\
\text { Positive presence } \\
\text { reactors of CPV }\end{array}$ & $\begin{array}{l}\text { Chi square } \\
\text { test }\end{array}$ \\
\hline $1-6$ months & Yes & 18 & 6 & & $33.33 \%$ & 0.06 \\
& No & 7 & 1 & & $14.28 \%$ & 0.0176 \\
$7-12$ months & Yes & 9 & 2 & $22.22 \%$ & 0.2718 \\
& No & 3 & 0 & 38 & $00.00 \%$ & \\
$13-18$ & Yes & 11 & 2 & & $00.18 \%$ & 2.11 \\
months & No & 2 & 0 & & & \\
Total & & & & & & \\
\hline
\end{tabular}

Table 3. Health status related prevalence of CPV in Dogs.

\begin{tabular}{lll}
\hline Health status of dogs & No. of dogs Affected. & Prevalence (\%) \\
\hline $\begin{array}{l}\text { Poor health } \\
\mathrm{n}=38\end{array}$ & 9 & $23.68 \%$ \\
$\begin{array}{l}\text { Normal health } \\
\mathrm{n}=12\end{array}$ & 2 & $16.66 \%$ \\
\hline
\end{tabular}


Table 4. Area wise prevalence of Canine parvovirus.

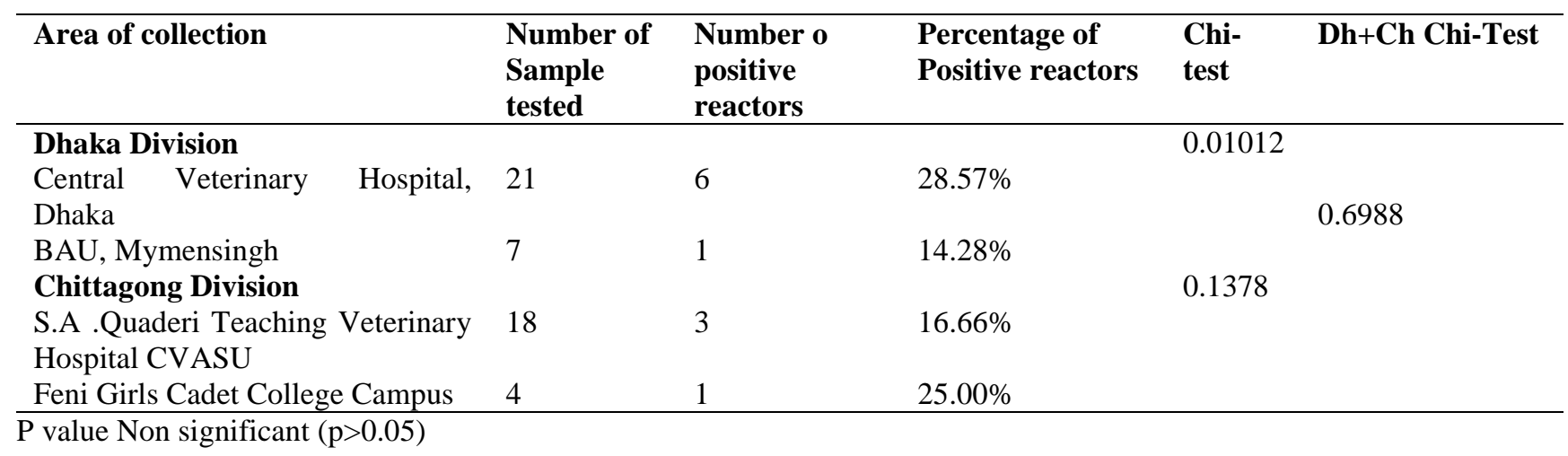

Table 5. Age related prevalence of Canine influenza virus.

\begin{tabular}{llllll}
\hline Age of the dog & $\begin{array}{l}\text { Number I } \\
\text { of } \\
\text { Sample } \\
\text { tested }\end{array}$ & $\begin{array}{l}\text { Number } \\
\text { of } \\
\text { positive } \\
\text { reactors }\end{array}$ & $\begin{array}{l}\text { Number } \\
\text { of } \\
\text { negative } \\
\text { reactors }\end{array}$ & $\begin{array}{l}\text { Percentage } \\
\text { of Positive } \\
\text { reactors }\end{array}$ & $\begin{array}{l}\text { Percentage of } \\
\text { negative } \\
\text { reactors }\end{array}$ \\
\hline 1-6 months & 22 & 0 & 22 & $0.00 \%$ & $100 \%$ \\
$7-12$ months & 13 & 0 & 13 & $0.00 \%$ & $100 \%$ \\
13-18 months & 11 & 0 & 11 & $0.00 \%$ & $100 \%$ \\
More than 18months & 4 & 0 & 4 & $0.00 \%$ & $100 \%$ \\
\hline
\end{tabular}

$\mathrm{P}$ value Non significant ( $\mathrm{p}>0.05)$

Table 6. Prevalence of canine influenza virus according to age and presence and /or absence of cough and nasal secretion.

\begin{tabular}{llllll}
\hline $\begin{array}{l}\text { Age of } \\
\text { Dog }\end{array}$ & $\begin{array}{l}\text { Presence of cough } \\
\text { and nasal secretion }\end{array}$ & $\begin{array}{l}\text { Number } \\
\text { of } \\
\text { Sample } \\
\text { tested }\end{array}$ & $\begin{array}{l}\text { Number } \\
\text { of } \\
\text { positive } \\
\text { reactors }\end{array}$ & $\begin{array}{l}\text { Total no. } \\
\text { of coughing } \\
\text { dogs }\end{array}$ & $\begin{array}{l}\text { Percentage of Positive } \\
\text { presence reactors of CIV }\end{array}$ \\
\hline $1-6$ months & Yes & 16 & 0 & & \\
& No & 6 & 0 & $00.00 \%$ \\
$7-12$ months & Yes & 9 & 0 & & $00.00 \%$ \\
& No & 4 & 0 & 36 & $00.00 \%$ \\
$13-18$ months & Yes & 8 & 0 & $00.00 \%$ \\
& No & 3 & 0 & & $00.00 \%$ \\
$>18$ months & Yes & 3 & 0 & $00.00 \%$ \\
& No & 1 & 0 & & $00.00 \%$ \\
\hline
\end{tabular}

P Value NS means Not significant ( $\mathrm{p}>0.05)$

Table 7. Area wise prevalence of Canine influenza virus.

\begin{tabular}{llll}
\hline Area of collection & $\begin{array}{l}\text { Number of } \\
\text { Sample tested }\end{array}$ & $\begin{array}{l}\text { Number of positive } \\
\text { reactors }\end{array}$ & $\begin{array}{l}\text { Percentage of } \\
\text { Positive reactors }\end{array}$ \\
\hline $\begin{array}{l}\text { Dhaka Division } \\
\text { Central Veterinary Hospital, Dhaka }\end{array}$ & 23 & 0 & $00.00 \%$ \\
$\begin{array}{l}\text { BAU, Mymensingh } \\
\text { Chittagong Division }\end{array}$ & 5 & 0 & $00.00 \%$ \\
$\begin{array}{l}\text { S.A.Quaderi Teaching Veterinary } \\
\text { Hospital CVASU }\end{array}$ & 17 & 0 & $00.00 \%$ \\
Feni Girls Cadet College Campus & 5 & 0 & $00.00 \%$ \\
\hline
\end{tabular}

$\mathrm{P}$ value Non significant $(\mathrm{p}>0.05)$

\section{Discussion}

There are several diagnostic methods to detect canine parvovirus infection and canine influenza virus infection in dog but the RapiGEN Canine Parvo Ag test is one of the most reliable and rapid one-step test based on the immune chromatographic assay of canine parvovirus antigen in canine feces. In Bangladesh we found 22.0\% 
(street dog is $18.18 \%$ and pet dogs is $23.07 \%$ ) were affected by canine parvovirus which is lower than 77.0 $80.4 \%$ reported by Decaro et al. (2007) but much higher than $6.2 \%$ reported by Grigonis et al. (2002). So the prevalence of canine parvovirus infection in Bangladesh is considerably high. The current study revealed high prevalence of this disease in pet dogs than street dogs.

The age wise incidence rates of different diseases have been summarized and presented in this study. The prevalence of canine parvovirus is relatively high (28.0\%) in 1-6 months and (16.16\%) 7-12 months age group which is much higher (16.8-18.3\%) than reported by Grigonis et al.(2002) but much lower (83.8) than that reported by Parthihan et al. (2010). In the current study the prevalence of canine parvovirus infection in dogs of' 1-6 months age group was found 2.52 times higher than that of 13-18 months (11.11\%) and 1.12 times higher than that of above 18 months age group (25.0\%). Whereas 4/25 (16\%) puppies were affected by canine parvovirus infection. In the present study the prevalence of canine parvovirus was found relatively higher in male $(24.13 \%)$ compare to female $(19.04 \%)$.

The current study revealed that there is a significant relationship between presence of diarrhea and canine parvovirus infection in dog of all age groups which was 33.33\% in 1-6 months age group, $22.22 \%$ in 7-12 months age group, $14.28 \%$ in 13-18 months age group and $25.00 \%$ in dogs of above 18 months of age. According to the study the overall prevalence of canine parvovirus in dogs having diarrhea during sample collection was $26.31 \%$ (10 out of 38 ).

\section{Conclusions}

As the RapIGEN4 Canine Parvo Virus Ag Test Kit and the RapIGEN4 Canine influenza Virus Ag Test Kit are very simple, quick and it does not require any special equipment's, the test kit may be recommended to be adopted in animal clinics for diagnosis of canine parvovirus infection in Bangladesh. This is the first time report about the prevalence of canine parvovirus and canine influenza virus infection in street and pet dogs of Dhaka and Chittagong Division in Bangladesh.

\section{Conflict of interest}

None to declare.

\section{References}

Chang SF, JY Sgro and CR Parrish, 1992. Multiple amino acids in the capsid structure of canine parvo-virus coordinately determine the canine host range and specific antigenic and hemagglutination properties. J. Virol., 66: 6858-6867.

Decora N, C Desario, G Elia, A Campolo and A Lorusso, 2007. Occurrence of severegastroenteritis in pups after canine parvo virus vaccine administration. A clinical and laboratory dilemma. Vaccine, 25: 1161-1167.

Grigonis A, V Macijauskas and G Zamokas, 2002. Examination of liver functions in dogs with parvovirus enteritis. Veterinarija-ir-Zootechnika, 17: 23-28.

Llamas-Saiz AL, M Agbandje-McKenna, JSL Parker, ATM Wahid, CR Parrish and MG Rossmann, 1996. Structural analysis of a mutation in canine parvovirus which controls antigenicity and host range. Virology, 225: 65-71.

Parrish R, 1990. Mapping specific functions in the capsid structure of canine parvovirus and feline panleukopenia virus using infectious plasmid clones. Virology, 183: 195-205.

Parthiban HK, Mukhopadhayay, PX Antony and RM Pilli, 2010. Epidemiology of canine parvovirus enteritis in pet dog in puducherry. Anim. Sci. Reporter, 4: 98-102.

Reed AP, EV Jones and TJ Miller, 1988. Nucleotide sequence and genome organization of canine parvovirus. J. Virol., 62: 266-276.

Steinel A, CR Parrish, ME Bloom and U Truyen, 2001. Parvovirus infections in wild carnivores. J. Wildl Dis., 37: 594-607.

Truyen U, A Gruenberg, SF Chang, B Obermaier, P Veijalainen and CR Parrish, 1995. Evolution of the feline-subgroup parvoviruses and the control of canine host range in vivo. J Virol., 69: 4702-4710. 